\title{
Ortaokul Öğrencilerinin Tıbbi Iş̧lem Korkuları ve Etkileyen Faktörler
}

\section{The Fears of High School Children from Medical Procedures and Affecting Factors}

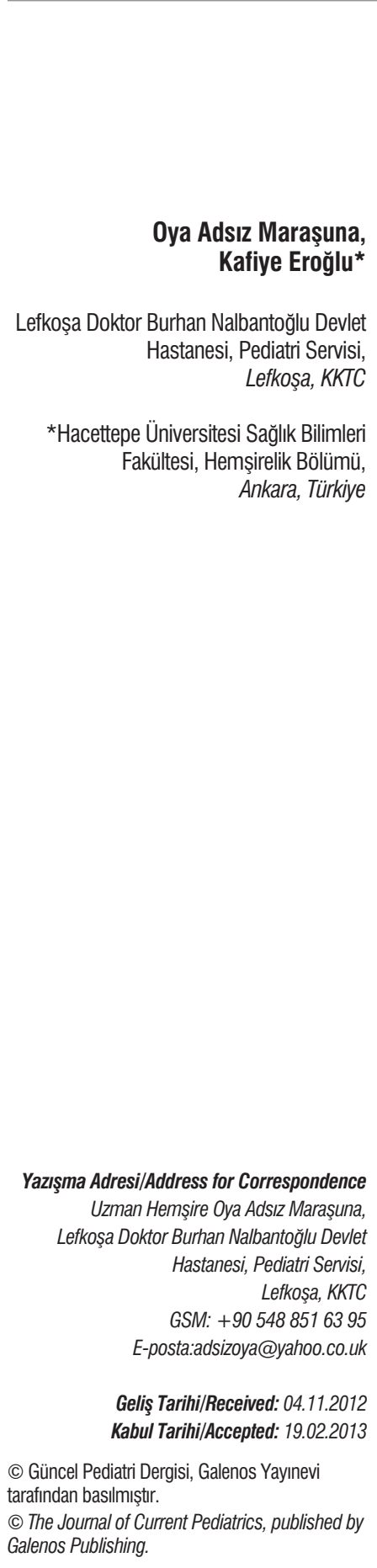

\section{ÖZET}

Giriş: Bu çalışma ortaokul çocuklarının tıbbi işlem korkularını ve etkileyen faktörleri belirlemek amacıyla tanımlayıcı olarak yapıımışıı.

Gereç ve Yöntem: Örneklem seçiminde öncelikle Mağusa bölgesindeki ortaokullar kırsal ve kentsel okullar olarak gruplandırımış ve tabakalı örnekleme yöntemi ile alınacak öğrenci sayısı evrenin bilindiği durumlarda örneklem hesabı formülü ile belirlenmiştir. Daha sonra her bir okuldan alınacak öğrenci sayısının yarısını kız, diğer yarıını erkek öğrenciler oluşturacak şekilde basit rastgele örneklem yöntemi ile 332 öğrenci çalışmaya alınmıştır. Veriler Tıbbi Işlem Korku Ölçeği ve Tanımlayıcı Soru Formu araciığı ile toplanmıştır. Verilerin değerlendirilmesinde, yüzde, ortalama, t-test'i ve tek yönlü varyans analizi (Anova) kullanılmıştır.

Bulgular: Çalışmada öğrencilerin toplam tıbbi işlem korku puan ortalaması 42,14 9,73 olup, 'biraz korkan' grupta yer aldıkları tespit edilmiştir. Öğrencilerin \%87,3'ünün tıbbi işlemlerden biraz korktuğu, \%4,8'inin hiç korkmadığı, \%7,8'inin ise çok korktuğu belirlenmiştir. Hastanede yatma nedenleri, yatma süresi, daha önce yapıımış tanı ve tedavi yöntemleri (ağız muayenesi hariç), daha önce uygulanmış tedaviler, ebeveyn mesleği, gelir düzeyi, annenin eğitim düzeyi ile tıbbi işlem korku puanları arasındaki farklar istatistiksel açıdan anlamsız $(p>0,05)$ bulunmuştur. Buna karşıllk cinsiyet ve babanın eğitim düzeyi ile toplam tıbbi işlem korku puanı ve korkunun dört boyutunda istatistiksel olarak anlamlı farklar saptanmışır $(p<0,01)$. Kız öğrencilerin ortalama korku puanları 44,74 $\pm 10,25$; erkek öğrencilerinki ise $39,61 \pm 8,48$ olarak bulunmuştur. Babası okuryazar olanların ortalama korku puanı $50,29 \pm 11,53$ iken babası üniversite mezunu olanların ortalama korku puanı $41,16 \pm 10,18$ olarak saptanmıştır. Ağı muayenesi, yaş değişkenleri ile tıbbi işlem korkusunun işlemsel, çevresel, kişisel ve kişilerarası korku boyutları arasında anlamlı farklar saptanmıştır $(p<0,05)$.

Sonuç: Çocukların tıbbi ișlem korkularının olumlu hekim-hemşire ilișkisi ile azaltılabileceği ve sağlık personelinin sevecen yaklaşımlarla yapılacak işlemleri açıklamalarının korkuları azaltmada etkili olacağı sonucuna varılmışıı. (Güncel Pediatri 2013; 11: 13-22)

Anahtar kelimeler: Okul çocuğu, korku, tıbbi işlem, uygulama, hemşire

\section{SUMMARY}

Introduction: This study is a descriptive study aiming to define the fears of medical procedures and factors affecting them in high school children.

Materials and Methods: At first students were grouped according to rural and urban schools in Famagusta and the study population in both areas was calculated by using the formula for cases in which the study population is known. By enrolling an equal number of male and female participants from each school by simple randomization, a total of 332 students were enrolled. Data was collected by using the Fear for Medical Procedures Scale and the Descriptive Questionnaire. The data was evaluated by using means, percentages, t-test and variance analysis (Anova).

Results: The mean medical fear score of the entire students was $42.14 \pm 9.73$ referring to the group of 'moderate fear'. Of the students $87.3 \%$ were in the group of 'moderate fear', $4.8 \%$ in the group of 'no fear' and $7.8 \%$ in the group of 'high fear'. No statistical significance was found between hospitalization etiology, hospitalization period, previous treatments and examinations (except oral examination), mother and father's occupation, mother's education level and the Medical Procedure Fear Scale $(p>0.05)$. On the other hand, statistically significant differences were found between gender, father's education level and total fear score. The mean total fear 
score of girls was $44.74 \pm 10.25$ and of boys was $39.61 \pm 8.48$. Mean fear score of students whom father's education was limited to reading and writing was $50.29 \pm 11.53$ and for those whose fathers were university graduates it was $41.16 \pm 10.18$. Statistically significant differences were found between number of brothers and sisters, age, oral examination history and operational, environmental and interpersonal dimensions of the Medical Procedure Fear Scale $(p<0.05)$.

Conclusions: These results suggest that fears could be reduced by doctor-nurse relationships and kind approaches of medical staffs towards students could have positive effects on the fears of students from medical procedures. (Journal of Current Pediatrics 2013; 11: 13-22)

Key words: School age, fear, medical procedure, procedure, nurse

\section{Giriş}

Insanın kültürel ve sosyal boyutunun geliştiği önemli alanlardan biri okuldur. Okul çağı 6-12 yaş çocukları kapsamakta olup bu dönemin temel özellikleri arasında korkular da yer almaktadır (1-5). Korku; belli gerçek veya gerçek olmayan bir durum ve tehlike karşısında ortaya çıkan ani, emosyonel istenmeyen bir davranış ve duygusal bir tepkidir (6-8).

Bugün yaşadığımız birçok korku temelini çocukluk yıllarından almaktadır. Yetişkinlerde yapılan araştırmalarda çocukluk korkularının \%40'ından fazlasının ileri yaşlarda da devam ettiği saptanmıştır (9-11). Korku, çocuklarda hayatın baskılarına göğüs germe yerine, yeteneklerini sınırlayan bir etken olabilir ve onların kaynaklarını harekete geçirme yerine onları hareketsiz kılabilir (11). Korkuların yaklaşık \%5'i kalıcı özelliktedir (12). Bu durum konunun ele alınmasını gerektiren önemli bir etkendir. Orta öğretim çocuklarında en sık görülen korkular; karanlık, ceza, yalnız kalmak, yaralanmak, sınavlar, notlar, kaçırımak, nükleer savaş, okul başarısızlığı, kişisel ilişkiler, cinsel korkular, ailevi endişeler ve tıbbi işlem korkularıdır $(9,11,12)$.

Korkular içinde yer alan yaralanmak ve tıbbi işlem korkuları çocukların sağlık uygulamalarına katılımını azaltıp, hastalık durumunda sağlık hizmeti almasını engelleyebilmekte ve tedavi sürecini olumsuz etkileyebilmektedir $(13,14)$. Literatürde hastalıkları tanımlayıcı veya tedavi edici uygulamaların tümüne tıbbi işlem denmektedir $(9,15,16)$. Bazı araştırmacılar tıbbi işlem korkusunun travmatik deneyimler veya sosyal öğrenme ile oluşabileceğini vurgulamıştır $(15,17)$. Okul çağı çocuklarının sağlıkla ilgili korkuları arasında; doktorhemşire korkusu, kan aldırma, hastanede yatma, muayene olma, ilaç içme, vücut fonksiyonlarını kaybetme, ameliyat olma, kontrolünü kaybetme, ölüm ve aileden ayrılma gibi korkuların yer aldığı belirtilmektedir $(13,15,18,19)$.

Okul çağı çocuklarının tıbbi işlem korkularını etkileyen faktörlere baktığımızda; daha önceki iyi-kötü hastane deneyimleri, bilişsel ve algısal yetenekleri, hastalığın yapısı ve şiddeti, sosyal destek sistemleriyle ilgili özellikler, yaş ve cinsiyet, hastanede yatış süresinin uzaması, anne babanın eğitim düzeyleri ve meslekleri karşımıza çıkmaktadır $(9,20-24)$. Yapılan çalışmalarda tıbbi işlem korkusunun gelişiminde farklı nedenler ileri sürülmüştür. Kunzelman ve Dünninger'in (19) çalışmasında, korkunun oluşmasında kişinin tıbbi işlemlerle ilgili travmatik bir deneyim geçirmesinin, aile üyelerinin korku davranışı sergilemesinin ve kişinin de bu davranışları model olarak almasının etkili olduğu belirtilmiştir. Stouthard ve Hoogstraten (17), tıbbi işlem korkusunun özelikle hekim tarafından yapılan açıklamalar sırasında artığını saptamışlardır.

Tıbbi işlem korkularının giderilmesine yönelik yapılan çalışmalara baktığımızda; hastanede yatan çocuklara yapılacak işlemlere yönelik eğitim verildiğinde tıbbi işlem korkularının azaldığı belirtilmektedir $(11,25)$. Yurtdışında bu konu ile ilgili yapılan çalışmalarda, hastanede yatan çocukların işlem öncesi eğitimle korkuların azalmasına yönelik çalışmalara rastlanırken $(12,14,15,17,19,26-29)$, sağlıklı okul çocukların tıbbi işlem korkusu ile ilgili bir çalışmaya rastlanmış olup, Kuzey Kıbrıs Türk Cumhuriyeti (KKTC)'de bu konuyla ilgili bir çalışmaya ulaşılamamıştır (30). Dolayısı ile çocukların tıbbi işlem korkularının giderilmesinde özellikle hastanede çocukları ilk karşılayan ve en fazla birlikte olan hemşirelere ve bütün sağlık çalışanlarına önemli sorumluluklar düşmektedir.

Çocuk sağlığı hemşireliğinin felsefesi aile ve toplum merkezlidir. Hemşireler çocukların sağlık düzeylerinin geliştirilmesinde önemli bir role sahiptir. Çocuk sağlığı hemşiresi, sadece yatan hasta bakımında değil, hastalıkların ve kazaların önlenmesinde, bütüncül sağlık yaklaşımı ile çocuğun aile içindeki bakımında rol alarak, çocukların tıbbi işlem korkularının önlenmesini veya azaltılmasını sağlayabilir, tedavi sürecine yansıyacak olumsuzlukları kontrol edebilir. Hemşirelerin konu ile ilgili müdahalede bulunabilmeleri için öncelikle mevcut durumun tanımlanması gerekmektedir $(3,31)$. Bu nedenle çalışmada öncelikle sağlıklı ortaokul çocuklarının tıbbi işlem korkularının ve korkuyu etkileyen faktörlerin belirlenmesi amaçlanmıştır. 


\section{Gereç ve Yöntem}

Bu çalışma, Mağusa bölgesinde 3'ü kırsal, 3'ü kentsel bölgede yer alan toplam 6 ortaokulda yapılmış tanımlayıcı bir çalışmadır.

Araştırmanın grubunu 2007-2008 yılı Milli Eğitim Bakanlığı istatistiklerine göre Mağusa bölgesi ortaöğretimde yer alan 2365 öğrenci olușturmuştur. Bu öğrencilerin 1126'sı kız, 1239'u erkektir. Örneklem büyüklüğü, Evreni Bilinen Durumlarda Örneklem Hesabı Formülü (9) kullanılarak hesaplanmıs olup 330 olarak belirlenmiștir. Örneklemde öncelikle kırsal ve kentsel tabakalı örnekleme yöntemiyle alınacak öğrenci sayısı belirlenmiştir. Daha sonra her bir okuldan tabaka ağırlığına ve cinsiyete göre eşit sayıda 332 öğrenci alınmıștır. Olasılıklı örnekleme yöntemlerinden basit rastgele örnekleme ile evrendeki öğrenciler listelenip numaralandıktan sonra rastgele sayılar tablosu kullanılarak örnekleme alınacak öğrenciler belirlenmiștir.

Veriler Tanımlayıcı Soru Formu ve Tıbbi Işlem Korku Ölçeği aracılığı ile toplanmıştır. Araştırmacı tarafından geliştirilen tanımlayıcı soruların anlaşılabilirliği ile ölçek sorularını cevaplamada sıkıntılarını belirlemek amacı ile Lefkoşa bölgesinde rastgele seçilen bir okulda örneklemin \%10'unu oluşturan 34 öğrenciye (17 kız, 17 erkek) ön uygulama yapıImıştır. Yapılan ön uygulama sonrası içerik ve anlaşılabilirlik açısından tekrar gözden geçirilen veri toplama formlarına son şekli verilmiştir.

Tanımlayıcı soru formunda çocuklara ve ebeveynlerine yönelik sosyo-demografik özellikleri içeren 10 soru, çocukların tıbbi işlem korkularını etkileyebilecek değişkenleri içeren 11 soru olmak üzere toplam 21 soru yer almıştır. Tıbbi Işlem Korku Ölçeği, Marion Bloom ve arkadaşları tarafından 1985 yılında geliştirilmiş, çocukların tıbbi işlem ve uygulamalarla ilgili korkularını ölçmeye yönelik bir ölçektir. Tıbbi korkular 29 soru olarak ele alınmıştır. Ölçek dört alt boyuttan oluşmaktadır. Tıbbi Işlem Korku Ölçeğinin güvenirliliği; tutarlılık katsayısı tüm test için Cronbach $\alpha=0,93$, ölçeğin geçerliliği 0,78 bulunmuştur. Bizim çalışmamızda Cronbach $\alpha=0,82$ bulunmuştur. ÖIçeğin Türkiye'deki geçerlilik güvenilirlik çalışması, Alak (9) tarafından yapılmıştır. Ölçeğin güvenirliği Split-Half Güvenirlik Ölçütü ve Spearman Brown Tekniği kullanılarak saptanmıştır. Alak'ın 7-14 yaş grubu 100 sağlıklı okul çocuğuyla yaptığı çalışmasında, güvenirlik analizlerinde Spearman Brown güvenirlik katsayısı 0,93 olarak bulunmuştur. Ölçeğin toplam soru sayısı 29 olup, ölçekten alınan en düşük puan 29, en yüksek puan ise 87 'dir. Ölçek, üç seçenekli Likert tipi bir ölçektir. Çocuktan ölçekteki her bir madde için "hiç korkmam" (1) , "biraz korkarım" (2), "çok korkarım" (3) ifadelerinden birini seçmesi istenmektedir. Ölçekten 0-29 puan alan hiç korkmayan;
29-58 puan arası alan biraz korkan; 58-87 puan arası alan öğrenci ise çok korkan olarak değerlendirilmektedir.

Alt Ölçeklerin değerlendirilmesi; Işlemsel maddelerin en düşük puanı 9, en yüksek puanı 27'dir. Çevresel maddelerin en düşük puanı 7 , en yüksek puanı ise 21 'dir. Kişisel maddelerin en düşük puanı 4, en yüksek puanı 12 'dir. Kişilerarası maddelerin en düşük puanı 9 , en yüksek puanı ise 27'dir. Çalıșmada tanımlayıcı soru formunun (5-10 dakika) ve ölçeğinin (15 dakika) cevaplama süresi belirlenmiștir.

Çalışma için Milli Eğitim Bakanlığı, Talim ve Terbiye Kurulu'ndan yazılı izin alınmıştır. Çalışma öncesi okul müdürleri ve rehber öğretmenler ile görüşerek çalışma hakkında ön bilgi verilmiştir. Veriler araştırmacı tarafından, her bir okula gidilerek tek oturumda toplanmış ve uygulama için rehber öğretmenlerden yardım alınmıştır. Formları her öğrencinin tek başına doldurması sağlanmıştır. Çalışmaya katılan öğrencilere araștırmacıya ulașabilecekleri telefon numaraları verilmiştir. Araştırma sonuçları sadece Mağusa Bölgesi ortaokul öğrencilerine genellenebilir.

Araştırmada elde edilen veriler bilgisayar ortamında Statistical Package For The Social Sciences for Windows 15.0 (SPSS 15.0) kullanılarak değerlendirilmiştir. Araştırmanın bağımsız değişkenleri; cinsiyet, sınıf, yaş, kardeş sayısı, anne ve babanın eğitim düzeyi, anne ve babanın gelir getiren işi-mesleği, daha önce hastaneye gitmesi ve nedeni, daha önce yapılmış olan tanı ve tedaviler, ailesinden birinin hastaneye yatması, öğrencinin daha önce hastaneye yatışı ve süresidir. Araştıranın bağımlı değişkeni ise tıbbi işlem korku puanıdır. Bağımsız değişkenlerin istatistiksel değerlendirmesinde yüzde, ortalama, standart sapma, minimum ve maksimum değerler; bağımlı ve bağımsız değişkenlerin karşılaştırımasında t-test'i ve tek yönlü varyans analizi (Anova) kullanılmıştır.

\section{Bulgular}

Öğrencilerin tanımlayıcı özelliklerine bakıldığında \%36,4'ü orta bir, \%42,5'i orta iki, \%21,1'i orta üçüncü sınıfta okuduğu; \%63,9'unun 11-12 yaş grubunda yer aldığı; \%38,6'sının ise bir kardeşe sahip olduğu görüldü. Ebeveynlerin özeliklerine bakıldığında, annelerin \%48,7'si lise ve üstü eğitim almış olup, \%48,8'i gelir getiren iş sahibi ve bunların \%22,0'ı memur, \%18,4'ü ise ișçi statüsünde bulundu. Babaların eğitim düzeyleri ise $\% 49,1$ ile lise ve üstü eğitim almış olup, \%94,6'sı gelir getiren bir iş sahibi ve bunların \%33,5'i memur, \%30,7'si işçi, \%31,9'u ise serbest meslek sahibi olduğu saptandı.

Öğrencilerin tıbbi tedavi ve deneyimlerine bakıldığında ilk beş sırayı \%81,3 ile ağızdan ilaç içmek, \%72,9 ile ağızboğaz muayenesi, \%70,7 ile vücut sıcaklığına bakılması, 
$\% 61,2$ ile kan alınması ve $\% 51,5$ ile kulak muayenesi oluştururken en nadir deneyim ise \%21,1 ile kulağa ilaç uygulaması olduğu görüldü.

Tablo 1'de görüldüğg̈ gibi öğrencilerden $\% 40,1$ ile daha önce hastanede yatmıştır. Hastanede yatanların, \%47,4'ü enfeksiyon hastalıkları içinde yer alan ishal-kusma, ateş, grip, tonsilit-larenjit-farenjit, domuz gribi, idrar yolu enfeksiyonu, hepatit ve kabakulak geçirdikleri belirlendi. Öğrencilerin \%36,9'unun majör travma içinde yer alan; ameliyat, travma, kırı sorunu yaşadıkları bulundu. Öğrencilerin \%15,7' sinin ise diğer sebepler (ağrı, kusma-ishal, astım, sebebini bilmeme, güneş çarpması, transfüzyon, alerji, anemi, havale, yanık, dehidratasyon, Ailesel Akdeniz Ateşi ve kontrol muayenesi) nedeni ile hastaneye yattığı saptandı. Öğrencilerin hastanede yatış süreleri $\% 81,2$ 'sinde 1-7 gün, $\% 11,3$ 'ünde 8-14 gün, $\% 7,5^{\prime}$ inde ise 15 gün ve üzerinde bulundu.

Tablo 2'de görüldüğü gibi, öğrencilerin \%95,2'si daha önce büyük bir hastaneye gitmiş olup $\% 74,1$ 'inde hastaneye gitme nedeninin tetkik-tedavi olduğu görüldü. Öğrencilerin çoğunluğunun $(\% 80,1)$ ailesinden birisinin daha önce hastanede yatmış olduğu ve en fazla \%40,0 ile annelerinin yattığı saptanmıştır. Öğrencilerin ailelerinden birden fazla birinci derece akrabası (anne, baba, kardeşten en az ikisi) hastaneye yatanların oranı \%2,1 iken bu oran ikinci derece akrabalarda (teyze, dayı, amca, nene, dede, yenge, kuzen, enişte) ise \%24,1 olarak bulundu.

Tablo 3'te görüldüğü gibi öğrencilerin ortalama toplam tıbbi işlem korku puanı 42,34 $\pm 11,54$ olarak hesaplanmış olup, tıbbi işlem korku ölçeğine göre öğrencilerin 'biraz korkarım' grubunda yer aldıkları tespit edildi. Tıbbi işlem korkusunun dört boyutu

\begin{tabular}{|c|c|c|}
\hline Özellikler & $S$ & $\%$ \\
\hline \multicolumn{3}{|c|}{ Hastaneye yatma durumu $(n=332)$} \\
\hline Yatan & 133 & 40,1 \\
\hline Yatmayan & 199 & 59,9 \\
\hline \multicolumn{3}{|c|}{ Hastanede yatma süreleri $(n=133)$} \\
\hline Büyük travma* & 49 & 36,9 \\
\hline Enfeksiyon* & 63 & 47,4 \\
\hline Diğer* & 21 & 15,7 \\
\hline \multicolumn{3}{|c|}{ Yatma süreleri $(n=133)$} \\
\hline 1-7 gün yatan & 108 & 81,2 \\
\hline 8-14 gün yatan & 15 & 11,3 \\
\hline 15 gün ve üzeri yatan & 10 & 7,5 \\
\hline
\end{tabular}

incelendiğinde puanların dağılımının kişilerarası = $14,16 \pm 4,22$, işlemsel $=12,10 \pm 2,44$, çevresel $=$ $10,14 \pm 3,04$ ve kişisel $=5,94 \pm 1,84$ puan şeklinde dağıldığı saptandı.

Öğrencilerin tıbbi işlem korku düzeylerine göre dağllımına bakıldığında; \%87,3'ünün tıbbi işlemlerden biraz korktuğu, \%7,8'inin çok korktuğu, \%4,8'inin ise hiç korkmadığı belirlendi (Tablo 4).

Tablo 5'te öğrencilerin tanımlayıcı özelliklerine göre tıbbi işlem korku puanlarının dağılımına ilişkin bulgulara yer verilmiştir. Öğrencilerin yaş grupları ile toplam tıbbi işlem korku puanı arasında anlamlı bir fark bulunmazken $(p>0,05)$, alt korku puanları ile yaş arasındaki ilişkiye bakıldığında, 11-12 yaş grubu öğrencilerin ortalama

Tablo 2. Öğrencilerin ve aile üyelerinin hastanede bulunma ve yatma durumları

\begin{tabular}{|l|r|r|}
\hline Özellikler & S & $\%$ \\
\hline Hastanede bulunma durumu ( $\mathrm{n}=332)$ & 316 & 95,2 \\
\hline Bulunan & 16 & 4,8 \\
Bulunmayan & 32 & 10,1 \\
\hline Öğrencilerin hastanede bulunma nedenleri \\
\hline Ameliyat olma & 234 & 74,1 \\
Tetkik-tedavi & 43 & 13,6 \\
Ziyaret & 7 & 2,2 \\
Birden fazla neden belirten & 266 & 80,1 \\
\hline Aileden birinin hastanede yatma durumu $(\mathrm{n}=332)$ & 66 & 19,9 \\
\hline Yatan & \\
Yatmayan & 78 & 40,0 \\
\hline Aileden hastanede yatan kişi $(\mathrm{n}=195)$ & 41 & 21,2 \\
\hline Anne & 25 & 12,6 \\
Baba & 47 & 2,1 \\
Kardeş & 24,1 \\
Birden fazla 1. derece akraba* & \\
2. derece akraba* & \\
\hline *Gruplandırmalar bulgular içerisinde açıklanmışıı & \\
\hline
\end{tabular}

Tablo 3. Öğrencilerin tıbbi işlem korku ölçeği puanının dağılımı

\begin{tabular}{|l|c|c|l|l|}
\hline Korkunun boyutları & $\mathbf{n}$ & Min. & Mak. & X- \pm SS \\
\hline Işlemsel & 332 & 9 & 24 & $12,10 \pm 2,44$ \\
Çevresel & 332 & 7 & 21 & $10,14 \pm 3,04$ \\
Kişisel & 332 & 4 & 12 & $5,94 \pm 1,84$ \\
Kişilerarası & 332 & 9 & 27 & $14,16 \pm 4,22$ \\
\hline Toplam & 332 & 29 & 84 & $42,34 \pm 11,54$ \\
\hline
\end{tabular}


işlemsel korku puanı 13-14 yaş grubundan anlamlı düzeyde yüksek bulundu. Cinsiyet değişkenine göre korku puanı incelendiğinde kızların toplam ve alt grup korku puan ortalamalarının erkeklerden anlamlı düzeyde yüksek olduğu bulundu. Kardeşi olanlarla kardeş sahibi olmayanların korku puanı incelendiğinde aralarında istatistiksel açıdan anlamlı fark saptanmadı. Annenin eğitim düzeyi öğrencilerin tıbbi ișlem korku puanlarını etkilemediği saptandı. Ancak babanın eğitim düzeyi artıkça tüm boyutlarda korku puanlarının anlamlı düzeyde azaldığı saptandı. Eğitim düzeyi düşük babaların çocuklarının korku puanları daha yüksek bulundu.

Tablo 6'da görüldüğü gibi, daha önce hastaneye gitme deneyimine göre tıbbi işlem korku puanı istatistiksel açıdan anlamlı bir fark yaratmadığı saptandı. Daha önce 'diğer' başlığı altında toplanmış olan ağrı, kusma-ishal, astım, sebebini bilmeyenler, güneş çarpması, transfüzyon, alerji, anemi, havale, yanık, dehidratasyon, ailesel Akdeniz ateşi ve kontrol nedenleriyle hastaneye yatan çocuklarla hastaneye yatmamış, majör travma (ameliyat, travma, kırık) ve enfeksiyon (ishal-kusma, ateş, grip, tonsilitlarenjit-farenjit, domuz gribi, idrar yolu enfeksiyonu, hepatit ve kabakulak) nedeni ile yatmış çocuklar arasındaki fark istatistiksel olarak anlamlı bulundu $(p<0,05)$.

Daha önce ağız muayenesi yaptırmayanların işlemsel korku puanı ağız muayenesi yaptıranlara göre yüksek bulundu. Aradaki farkın istatistiksel olarak anlamlı olduğu görüldü $(p<0,05)$ (Tablo 7$)$.

\section{Tartıșma}

Tıbbi ișlem korkusu, tıbbi ișlemler veya tıbbi personelle ilgili bir deneyim veya hastane ortamında sağlık durumlarının değişmesi ile ilgili bir korkudur $(9,15,32)$. Tıbbi işlem korkuları çocukların sağlık uygulamalarına katılımını ve hastalık durumunda tedavi sürecini olumsuz etkileyebilmektedir $(5,18,33,34)$. Bu çalışma Tıbbi Işlem Korku Ölçeği kullanılarak ortaokullarda öğrenim gören sağlıklı öğrencilerin tıbbi işlem korkuları ve bunları etkileyen faktörleri belirlemek amacıyla yapılmıştır.

Çalışmada öğrencilerin toplam tıbbi işlem korku puan ortalaması 42,14 $\pm 9,73$ olup, 'biraz korkan' grupta yer

\begin{tabular}{|l|r|r|}
\hline \multicolumn{3}{|c|}{ Tablo 4. Öğrencilerin tıbbi işlem korku düzeylerinin dağılımı } \\
\hline Tıbbi işlem korku düzeyi & S & $\%$ \\
\hline Hiç korkmayan (0-29 puan) & 16 & 4,8 \\
Biraz korkan (29-58 Puan) & 290 & 87,3 \\
Çok korkan (58-87 puan) & 26 & 7,8 \\
\hline TOPLAM & 332 & 100,0 \\
\hline
\end{tabular}

aldıkları tespit edilmiştir. Öğrencilerin \%87,3'ünün tıbbi işlemlerden biraz korktuğu belirlenirken, \%4,8'inin hiç korkmadığı, \%7,8'inin ise çok korktuğu belirlenmiștir (Tablo 4). Alak'ın (9) ameliyat olmak üzere yatan 7-14 yaş grubu 100 çocukta yaptığı çalışmada çocukların toplam tıbbi işlem korku puan ortalaması 42,79 $\pm 9,96$ olup, bu araştırmayla benzer şekilde 'biraz korkan' grupta yer aldıkları belirlenmiştir. Görüldüğü gibi araştırma bulgularımız diğer çalışmalardaki bulgulara benzerdir. Bu çalışma sonuçları tıbbi işlem korkularının nedenlerini açığa çıkaracak çalışmalara gereksinim olduğunu göstermektedir.

Okul çağı çocuklarının tıbbi işlem korkularını etkileyen faktörlere yönelik çalışmalara bakıldığında; daha önceki iyi-kötü hastane deneyimleri, bilişsel ve algısal yetenekleri, hastalığın yapısı ve şiddeti, sosyal destek sistemleriyle ilgili özellikler, yaș ve cinsiyet hastanede yatış süresinin uzaması, anne babanın eğitim düzeyleri ve meslekleri karşımıza çıkmaktadır $(8,18,21,26)$.

Korku çocukların içinde bulunduğu yaş grubunun gelişimsel özelliklerine bağlı olarak değişim gösterir. Tıbbi işlem korkusunu etkileyen faktörlerden birisi yaştır. Korkunun en yoğun yaşandığı yıllar doğumdan sonraki iki yıl ve ergenlik yıllarıdır $(21,23,25,35,36)$. Araştırmada yaş, toplam tıbbi işlem korku puanını etkilemezken, korkunun dört boyutundan biri olan işlemsel korkuda, 11-12 yaşın 13-14 yaşa göre korku puanı istatistiksel açıdan anlamlı düzeyde yüksek $(p<0,05)$ bulunmuştur. Konu ile ilgili yapılan çalışmalara baktığımızda, yaş ilerledikçe bazı fobi ve korkuların gerilediği ve erişkin dönemde kaybolabildiği belirtilmiştir $(9,15,17,19,22,24,26,27,37-40)$. Araştırmaya alınan öğrencilerin yaşları bir birine yakın olduğu için literatürle karşılaştırmak doğru olmamakla birlikte literatürle benzer şekilde korkunun azalma sebebi yaşın artması ile ilgili olabileceği düșünülmüștür.

Korkuyu etkileyen önemli bir diğer faktör cinsiyettir. Yapılan araştırmalara göre kızların korku düzeylerinin erkeklerin korku düzeylerine göre daha yüksek olduğu, bunun sebebinin ise kız çocuklarının daha duygusal olması ile ilgili olabileceği belirtilmektedir $(21,25,36,41,42)$. Araştırmada cinsiyet ve tıbbi işlem korku puanları arsındaki fark kIz çocuklarda, erkek çocuklara göre korkunun her boyutunda ve toplam korku puanında istatistiksel olarak anlamlı $(p<0,01)$ şekilde daha yüksek tespit edilmiştir. Benzer şekilde, 7-19 yaş arası çocuklarla yapılan bir çalışmada kızların sadece tıbbi işlem korkusunun değil bütün korku tiplerinin (hayvan korkusu, ölüm korkusu, vs) erkeklere göre daha fazla olduğu bildirilmiştir (37). Konu ile ilgili bir başka çalışmada ise Nijerya, Amerika, Çin ve Avustralya'da aynı anda 8-17 yaş grubu üzerinde yapmış oldukları çalışmada da kız çocuklarının daha 


\begin{tabular}{|c|c|c|c|c|c|c|c|c|c|c|c|c|c|c|c|c|c|c|}
\hline & & 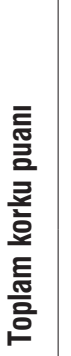 & $\begin{array}{l}\mathscr{\infty} \\
+1 \\
1 \times\end{array}$ & & 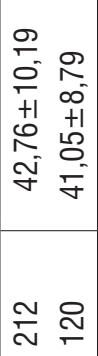 & $\mid$\begin{tabular}{l}
2 \\
0 \\
\hdashline \\
-
\end{tabular} & & 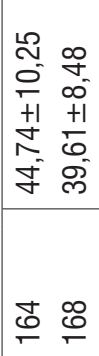 & $\begin{array}{l}8 \\
\mathscr{8} \\
\sigma \\
\sigma\end{array}$ & & 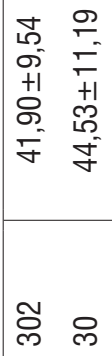 & $\underset{\substack{m \\
\leftarrow}}{\stackrel{m}{\sigma}}$ & & 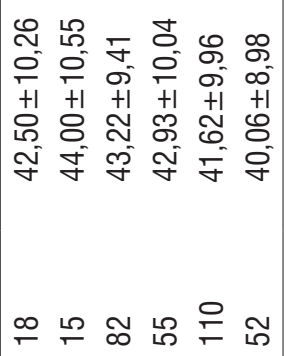 & $\begin{array}{l}\text { 离 } \\
\text { o }\end{array}$ & & 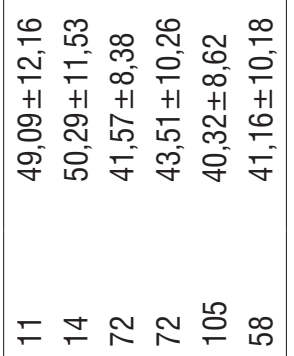 & $\begin{array}{l}0 \\
\hat{0} \\
0 \\
0 \\
0 \\
0 \\
0 \\
\hat{0} \\
0 \\
0 \\
0 \\
0 \\
\vdots \\
0 \\
0\end{array}$ \\
\hline & & 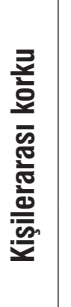 & $\begin{array}{l}\mathscr{y} \\
+1 \\
\mid x\end{array}$ & & 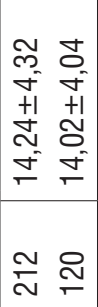 & $\mid \begin{array}{c}\text { 导 } \\
\text { ć }\end{array}$ & & 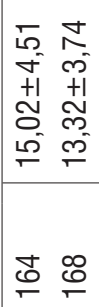 & $\begin{array}{l}\infty \\
\tilde{N} \\
\tilde{m}\end{array}$ & & 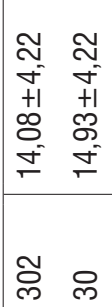 & $\stackrel{1}{2}$ & & 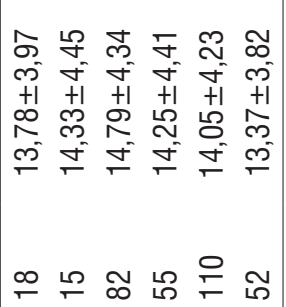 & 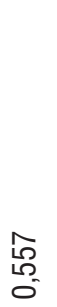 & & 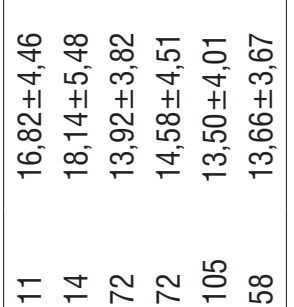 & 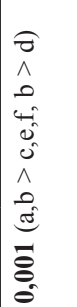 \\
\hline 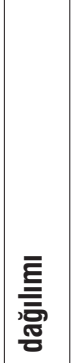 & 흫 & 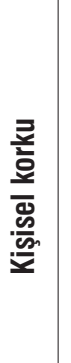 & $\begin{array}{l}\tilde{y} \\
+1 \\
+1\end{array}$ & & 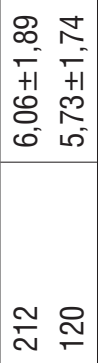 & 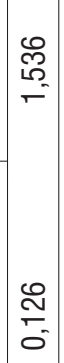 & & $\begin{array}{ll}8 & 8 \\
\text { i } & \frac{1}{2} \\
+1 & +1 \\
0 & +1 \\
0 & 5 \\
0 & 5 \\
0\end{array}$ & 흥 & & 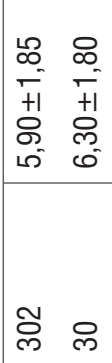 & 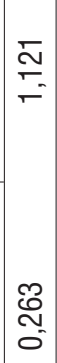 & & 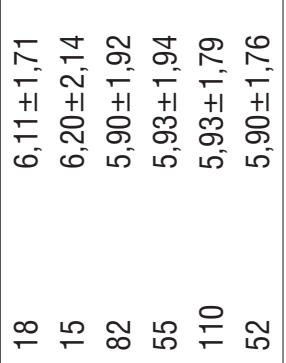 & $\begin{array}{l}\text { 尺े } \\
\text { Ö }\end{array}$ & & 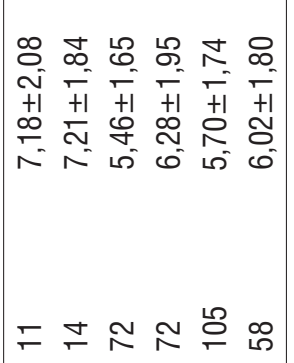 & 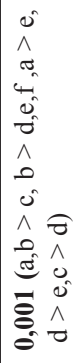 \\
\hline 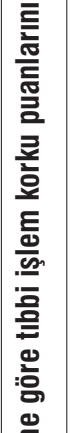 & 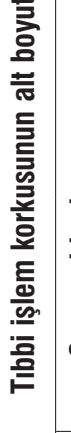 & 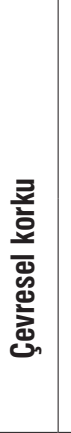 & $\begin{array}{l}\infty \\
0 \\
+1 \\
1 \times\end{array}$ & & 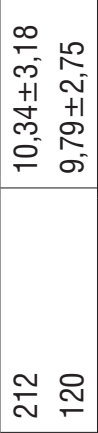 & 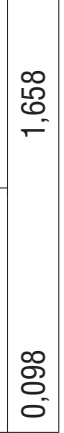 & & $\begin{array}{ll}\infty & 0 \\
N & 2 \\
\infty & 0 \\
+1 & +1 \\
N & +1 \\
0 & 0 \\
0 & 0 \\
0 & 0\end{array}$ & 客 & & 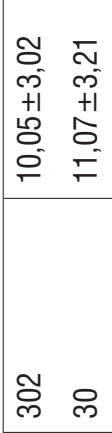 & $\begin{array}{l}\widetilde{1} \\
0 \\
0 \\
0\end{array}$ & & 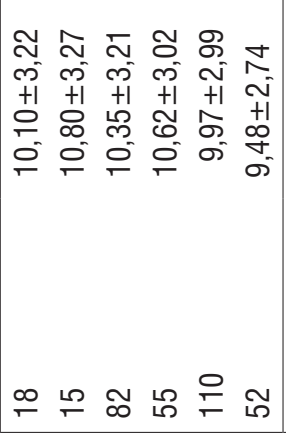 & $\begin{array}{l}\text { ○్లి } \\
\text { ○ }\end{array}$ & & 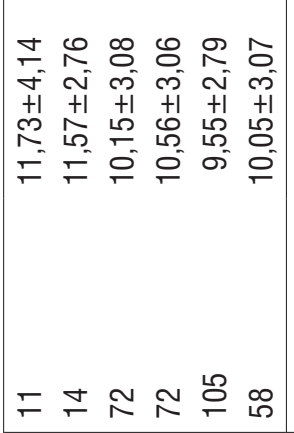 & 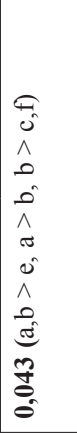 \\
\hline 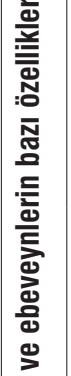 & & 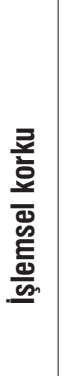 & $\begin{array}{l}\boldsymbol{\infty} \\
0 \\
+1 \\
|\downarrow| x\end{array}$ & & 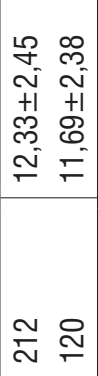 & $\begin{array}{l}\hat{o} \\
\text { N } \\
\sim\end{array}$ & & 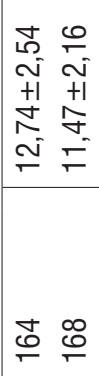 & $\begin{array}{l}\bar{\Phi} \\
\infty \\
\forall\end{array}$ & & 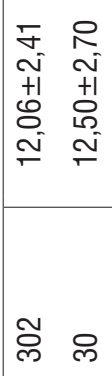 & 胥 & & 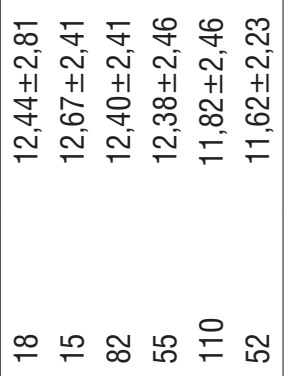 & 竎 & & 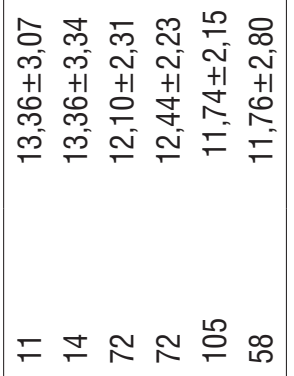 & 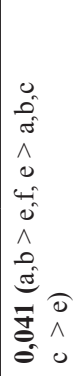 \\
\hline 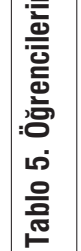 & & 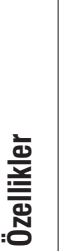 & & $\stackrel{\pi}{\tau}$ & 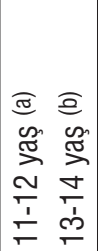 & + & & 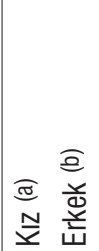 & - & & 㐫 & e & 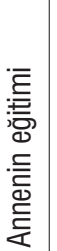 & 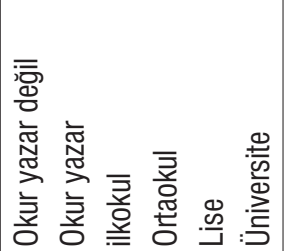 & 2 & 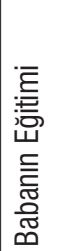 & 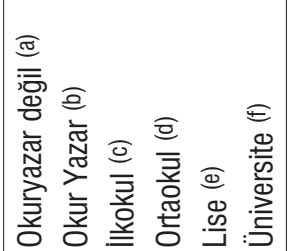 & $=$ \\
\hline
\end{tabular}




\begin{tabular}{|c|c|c|c|c|c|c|c|c|c|c|c|c|c|c|c|}
\hline \multirow{6}{*}{\multicolumn{2}{|c|}{ 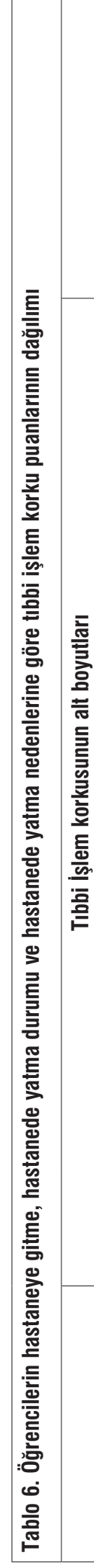 }} & 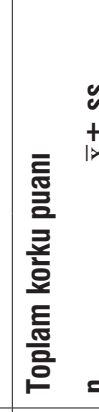 & & 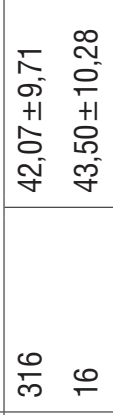 & $\begin{array}{l}10 \\
00 \\
10 \\
0\end{array}$ & & 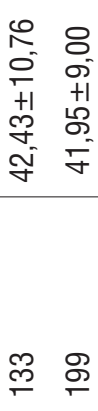 & $\mid \begin{array}{l}\mathscr{P} \\
\stackrel{\mathscr{c}}{0}\end{array}$ & & 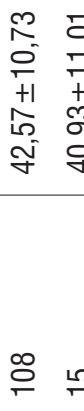 & 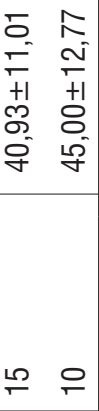 & $\begin{array}{l}9 \\
0 \\
0 \\
0 \\
0\end{array}$ & & 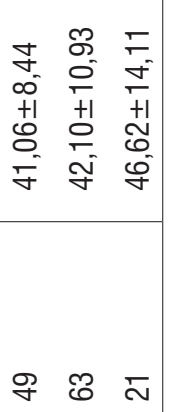 & $\frac{8}{0}$ \\
\hline & & 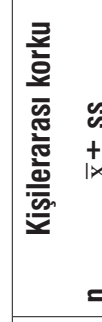 & & 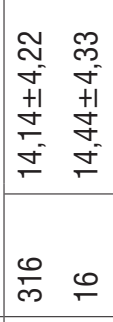 & 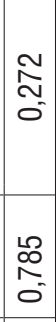 & & 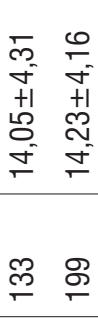 & $\begin{array}{l}0 \\
\mathbb{0} \\
0 \\
0\end{array}$ & & 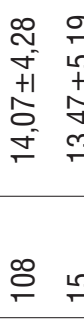 & 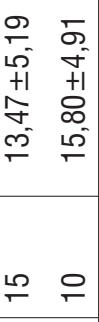 & $\begin{array}{l}1 \\
0 \\
10 \\
0 \\
0\end{array}$ & & 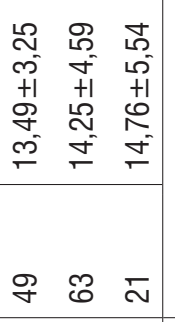 & $\begin{array}{l}0 \\
\tilde{0} \\
0\end{array}$ \\
\hline & & 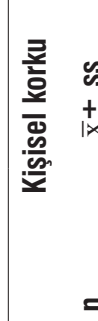 & & 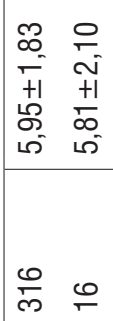 & $\begin{array}{l}\infty \\
\stackrel{N}{N} \\
0\end{array}$ & & 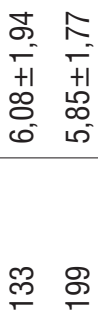 & $\begin{array}{l}\mathscr{O} \\
\stackrel{O}{O} \\
-\end{array}$ & & \begin{tabular}{ll}
$\infty$ & 0 \\
$o$ & \multicolumn{1}{c}{} \\
+ & + \\
+1 & + \\
0 & $\infty$ \\
0 & 0 \\
0 & 0
\end{tabular} & 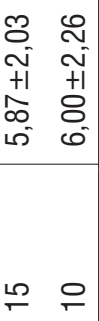 & $\mid \begin{array}{c}N \\
\tilde{1} \\
0 \\
0\end{array}$ & & 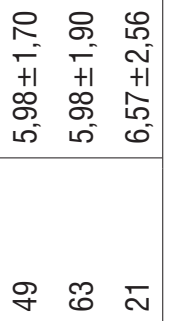 & 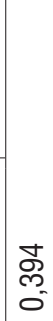 \\
\hline & & 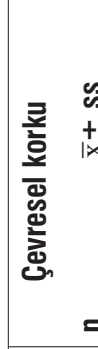 & & \begin{tabular}{ll}
$\sigma$ & 0 \\
0 & 0 \\
0 & 0 \\
+1 & +1 \\
$\stackrel{0}{N}$ & 0 \\
\hdashline & 0 \\
0 & 0
\end{tabular} & 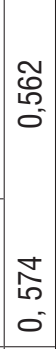 & & 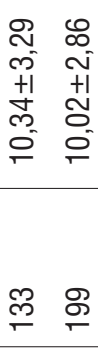 & $\left|\begin{array}{l}\overline{0} \\
\dot{0} \\
0\end{array}\right|$ & & 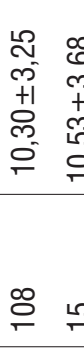 & $\begin{array}{ll}0 & \mathbb{N} \\
0 & 0 \\
0 & 0 \\
+1 & +1 \\
0 & 0 \\
0 & 0 \\
0 & 0 \\
0 & 0\end{array}$ & $\begin{array}{l}0 \\
0 \\
0 \\
0 \\
0\end{array}$ & & 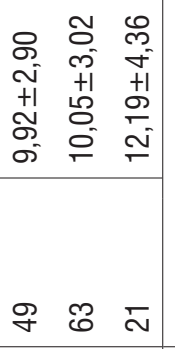 & 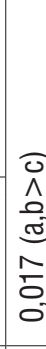 \\
\hline & & 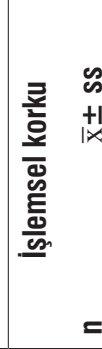 & & 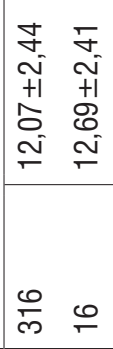 & $\begin{array}{l}\text { S } \\
\text { O. }\end{array}$ & & 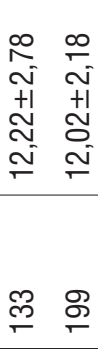 & $\begin{array}{l}i_{0}^{8} \\
0 \\
0\end{array}$ & & 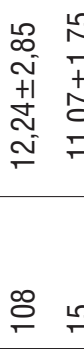 & 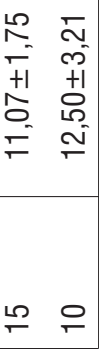 & 惢 & & 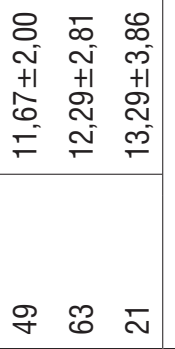 & $\begin{array}{l}\text { O } \\
\text { O } \\
0\end{array}$ \\
\hline & & 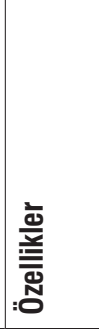 & 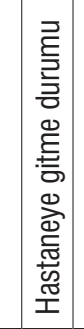 & 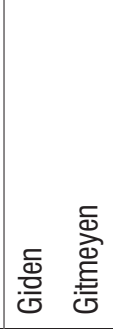 & 2 & 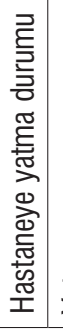 & 范 & & 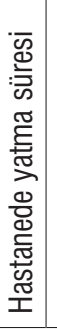 & 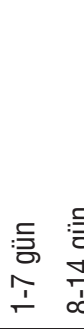 & 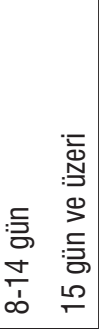 & & 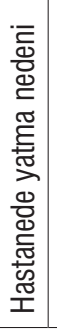 & 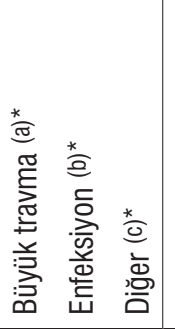 & \\
\hline
\end{tabular}




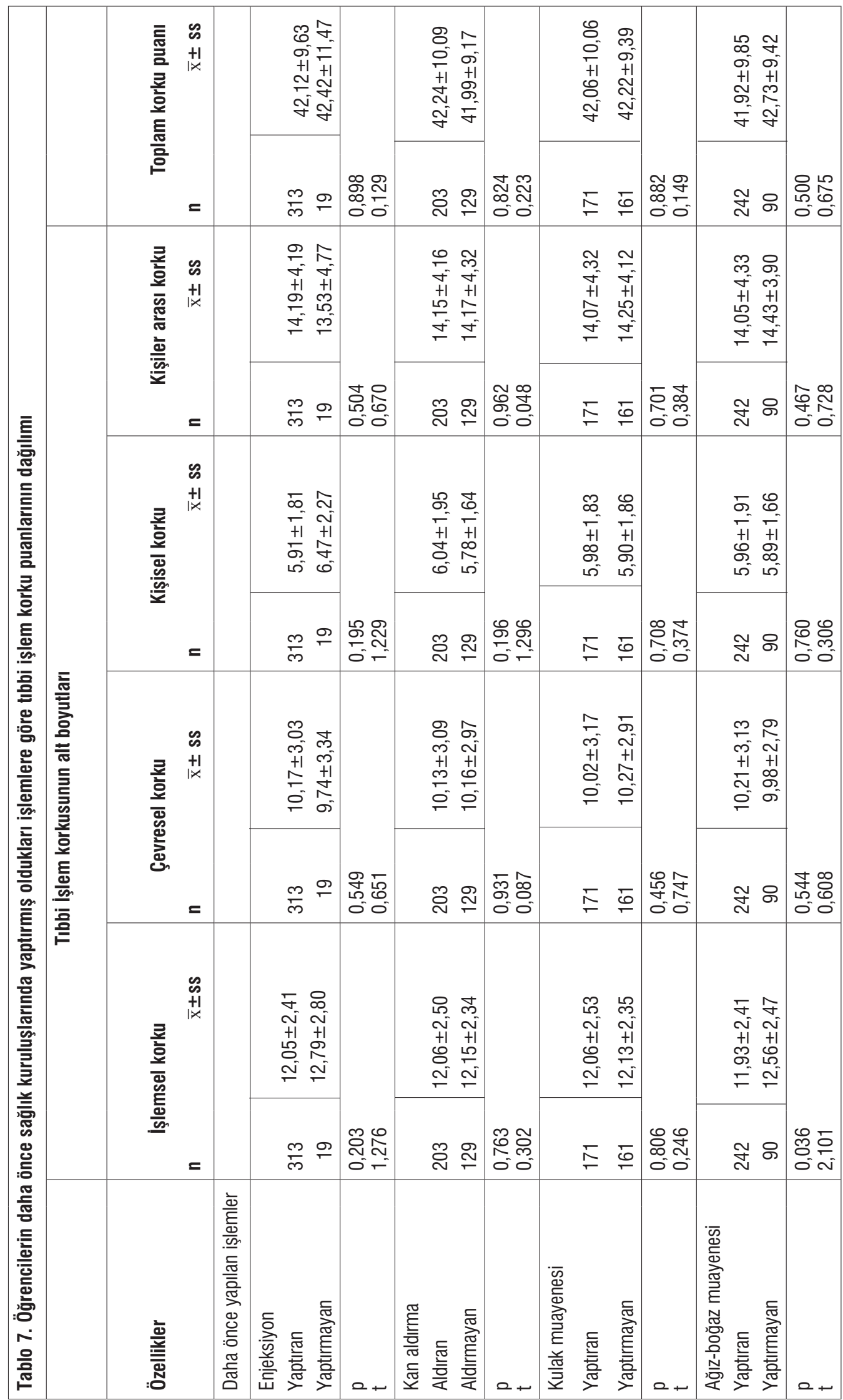


fazla etkilediği görülmüş olup korkunun kültürden kültüre, yetiştirme ve davranış tutumlarına bağlı olarak uluslararası değişiklik gösterdiği bildirilmiştir (40). Çalışmamızdaki kız öğrencilerin korku puanlarının erkek öğrencilerden daha yüksek oluşunu da kız çocuklarının duygularını daha kolay açıklamasını destekleyen ve onların güçsüz olabileceklerini kabul eden kültürel algı ile açıklanabilir.

Tıbbi işlem korkusunu etkileyen diğer faktörler ebeveyn eğitimi ve mesleğidir. Yapılan araştırmalarda babaların çocuklar için güçlü bir rol modeli olduğu, babanın çocukları ile geçirdikleri zamanın ve dolaylı etkileşiminin çocukların babalarını gözlemleme yoluyla birçok davranışı kazanmalarına yardımcı olduğu ortaya konmuștur $(8,24,34,43)$. Araştırmada çocukların annelerinin eğitim düzeyi, mesleği ve gelir getiren bir iște çalıșıp çalıșmaması çocuğun tıbbi işlem korku puanını etkilememiștir. Babanın eğitim durumu toplam tıbbi ișlem korkusu puanını ve korkunun dört boyutunu istatistiksel olarak anlamlı sekilde $(p<0,01)$ etkilemiștir. Eğitim düzeyi düșük babaların çocuklarının tüm korku puanları yüksek bulunmuștur. Konu ile ilgili yapılan çalıșmalarda, ilkokul mezunu olan ebeveyn ile yüksek okul mezunu olan ebeveynin çocuklarına uyguladıkları tutumlar farklılık gösterebildiği belirtilmektedir. Bu çalışmalarda anne-baba eğitim durumu ile çocukların sosyal korku-kaygı düzeyleri arasında anlamlı bir fark olduğunu, anne-babası yüksek okul mezunu olan çocukların korku-kaygı düzeylerinin düşük olduğunu belirlemiştir $(38,44,45)$. Araştırma sonucunda literatürle uyumlu olarak babaların eğitim düzeyi artıkça çocukların korku puanı azalmaktadır. Bunun sebebi ise, babanın çocukta yarattığı güvenin korkuyu azaltması olabilir.

Hastaneye yatma tıbbi işlem korkusunu etkileyen önemli bir faktördür. Hastane ortamı çocuk için onu korkutan rahatsız eden ve hoş olmayan deneyimleri içerir (3). Akut biçimde hastaneye yatırımış hastalar için hastane ortamı bilinmeyenden korkmaya bağlı anksiyeteye dönüșürken, kronik hastalarda daha önce yașanmıș travmatik olaylar, girișimsel uygulamalar hastaneye yatmaya bağlı stres yaratabilmektedir. Daha önce gerçekleştirilen çalışmalarda büyük travma geçirenlerde korku beklenirken bu çalışmada korku saptanmamıştır $(33,39,44-46)$. Bunun nedeni çalışmanın sağlıklı okul çocuklarına yapıımış olası ve geçmişi hatırlamıyor olmaları ile ilgili olabilir.

Daha önce hastaneye yatma deneyimi yaşamamış çocuklar ise, genellikle rutin muayeneleri, aşıları ya da geçirdikleri hastanede yatmayı gerektirmeyecek hastalıklar nedeniyle tedavi amaçlı hastaneye gelme ile bu deneyimi yaşamaktadırlar. Bu üç durumda da çocuklar ağrılı girişimlerle karşılaşacak, alışık olduğu yaşantısı kesintiye uğrayacak, fakat hastane imajı açısından gruplar arası faklılık görülmeyecektir $(18,26,32,39,47,48)$.
O'Conner-Von (39), çocukların yaşadığı hastane deneyiminin kendilerine güvenlerini artırdığını, streslerini kontrol etmede daha başarılı olduklarını belirtmiştir. Araştırmada daha önce hastaneye gidip gitmeme durumu ve hastaneye gitme nedenleri toplam tıbbi işlem korku puanını istatistiksel olarak anlamlı şekilde etkilememiştir. Daha önce uygulanmış tanı ve tedavi işlemleri toplam tıbbi işlem korku puanını etkilemezken, ağız muayenesi yaptırmayan çocukların, yaptıranlara göre ișlemsel korku puanları istatistiksel olarak anlamlı düzeyde yüksek $(p<0,05)$ bulunmuştur. Bunun sebebi ağız-boğaz muayenesine maruz kalanların ișlemin korkunç olmadığını fark etmiş olmaları olabilir. Bilinmeyen korkusu deneyimle yok olmuş olabilir.

Sonuç olarak, ortaokul çocuklarında toplam tıbbi ișlem korkusunun biraz olduğu ve bu korkuyu cinsiyet ve babanın eğitim düzeyi faktörlerinin etkilediği tespit edilmiştir. Bu korkunun varlığı niteliksel çalışmaların yanında korkuyu azaltıcı müdahale çalışmalarının yapıımasının gerekliliğini ortaya koymaktadır.

\section{Kaynaklar}

1. Arıkan, D. Çocuğun Hastaneye Hazırlanması. Türk Hemșireler Dergisi 1992;42:9-10.

2. Atay, M. Çocukluk Döneminde Gelişim. Ankara: Kök Yayıncılık; 2005;31-43.

3. Çakıroğlu S. Çocuk Hastaların Hastaneye Ilişkin Korkularının Araștırıması ve Korkunun Giderilmesinde Hemșirenin Rolü. II. Ulusal Hemşirelik Kongresi Bildiri Kitapçığı. 1990. s471- 472.

4. Yaramış N, Karakas N. Nevșehir II Merkezinde Ilköğretim Çağındaki Çocuklarda Göz Hastalıklarının Tespit Edilmesinde Hemşirenin Rolü. Sağlık Bilimleri Dergisi 2005;14:45-53.

5. Yavuzer H. Okul çağı çocuğu. Istanbul: Remzi kitap evi, 2004. s13-15.

6. Artan I, Bayhan P. Çocuk Gelişimi ve Eğitimi. Istanbul: Morpa Kültür Yayınlarl; 2005. s14-15.

7. Ekși, A. Ben Hasta Değlim, Cocuk Sağlığı ve Hastalıklarııın Psikolojik Yönü, Istanbul: Nobel Tıp Kitapevi; 1999. s374- 378.

8. Karagöz, S. Kronik Olan Hastalarda Ağrının Hafifletilmesinde Psikolojik Yaklaşımlar III. Ulusal Hemşirelik Kongresi Bildirileri. Izmir; 1990. s105.

9. Alak, V. Hastaneye Ameliyat Olmak Üzere Gelen 7- 14 Yaş Grubu Cocukların Korkuları ve Hemşirelik Uygulamaları. (Yayınlanmamış Tez).Ege Üniversitesi Sağlık Bilimleri Enstitüsü.' Doktora Tezi'. 1993; Izmir.

10. Güler G, Kubilay G. Bir Illköğretim Okulu Öğrencilerinin Fiziksel Bakım Sorunlarının Çözümlenmesinde Toplum Sağlı̆ı Hemşiresinin Etkinliği. C.Ü. Hemşirelik Yüksek Okulu Dergisi 2005;9:15-23.

11. Gültekin G, Baran B. Hastalık ve Cocuk. Aile ve Toplum Eğitim Kültür ve Araşıırma Dergisi 2005;7:54-61.

12. Craske MG. Fear and Anxiety in Children and Adolescent. Bull Menninger Clin 1997;61(2 Suppl A):A4-36. 
13. Cebiroğlu R. Çocuk akıl sağlığı ve hastalıkları. Cilt.17, Üni. Klinik Ders Kitapları, istanbul: Sanal Matbaacılık; 1982. s80-84.

14. Kavaklı A. Çocukluk Yaşlarında Büyüme ve Gelişme. Istanbul: Hilal Matbaacılık, 1992; 16- 25, 141-261.

15. Dona LW, Lucille F. The Child's Reaction to Illness and Hospitalization. Whaley and Wong's Nursing Care of Infant and Children 1996;863-93.

16. Ayhan A. Gelişim ve Öğrenme Psikolojisi, 2.Basım, Istanbul: Alfa Yayınları; 2000. s15-24.

17. Stouthard M, Hoogstraten J. Ratings of fears associated with twelve dental situations. J Dent Res 1987;66:1175-8.

18. Schulze Ö. Çocukların Içindeki Korkular, Beyaz Yayınları, Istanbul: 1998. s37-45.

19. Kunzelmann KH, Dünninger $P$. Dental fear and pain: effect on patient's perception of the dentist. Community Dent Oral Epidemiol 1990;18:264-6.

20. Başbakkal Z, Sönmez S, Celasin NS, Esenay F. 3-6 Yaş Grubu Çocuğun Akut Bir hastalık Nedeniyle Hastaneye Yatışa Karşı Davranışsal Tepkilerinin Belirlenmesi. Uluslar arası Insan Bilimleri Dergisi 2010;7:456-68.

21. Beck-Rawlins W, Clum, A. Mental health Psychiatric nursing (A holistic life-cycle approach). Toronto: the C. V. Mosby Comp., 1984, chapter 34, 1114-1118.

22. Ataman Z. Okul Çağı Çocuklarının Tıbbi Işlem Korkularına Yönelik Verilen Bilginin Etkisinin Incelenmesi. (Yayınlanmamış Tez).Dokuz Eylül Üniversitesi Çocuk Sağlığı ve Hastalıkları Hemșireliği Anabilim Dalı. Izmir,2006

23. Çavuşoğlu H. Çocuk Sağlığı Hemşireliği. Bizim Büro Basımevi. Ankara; 2008;1:47-64.

24. Gümüş A. Üniversite Öğrencilerinin Sosyal Kaygı Düzeylerinin Çeşitli Değişkenlere Göre Incelenmesi. Yüksek Lisans Tezi Gazi Ủniversitesi Sosyal Bilimler Enstitüsü. 1997.

25. Kang L. Childhood cognitive development. The Essential reading. UK: Blackwell publishing. 2000. s177-196.

26. Sargın N. Lise I. ve III. Sınıf Öğrencilerinin Durumluk-Sürekli Kaygı Düzeylerinin Belirlenip Karşılaştırılması. Yüksek Lisans Tezi, Dokuz Eylül Üniversitesi Sosyal Bilimler Enstitüsü. Yayınlanma yılı 2005.

27. Özusta HŞ. Çocuklar Için Durumlu-Sürekli Kaygı Envanteri. Uyarlama, Geçerlik ve Güvenirlik Çalışması. Türk Psikoloji Dergisi 1993;10:32-44

28. Erefe I. Okul Sağlığı. Halk Sağlığı Hemşireliği El Kitabı, Ankara: Vehbi Koç Yayınları, 1998ç s134- 153.

29. Majstorovic M, Veerkamp JS. Relationship Between Needle Phobia And Dental Anxiety. J Dent Child (Chic) 2004;71:201-5.

30. Kuzey Kıbrıs Türk Cumhuriyeti Milli Eğitim Bakanlığı 20072008 Ortaöğretim öğrenci istatikleri. http://www.mebnet. net/ $q$ = node/75. (Erişim 06 Mayıs 2010).
31. Smith DJ, Phyllis MD, White, PN, Poppen, WA. An Integetive Theoretical model of Children's Fears. Home Economic Research Journal 1990;151-8.

32. Berne E, Kapkın E. (Çev.), Psikiyatri ve Psikoanaliz Rehberi. Istanbul: Yaprak Yayınları, 1988. s115.

33. Burnham JJ, Gulone E. The Fear Survey Schedule for ChildrenII: A Psicometric Investigation with American Data. Behav Res Ther 1997;35:165-73.

34. Altıner F. Hastanede Yatan Çocuklarda Kısıtlama. T.H.D 1983;1:43-8.

35. Ronan KR, Kendall PC, Rowe M. Negative Affectivity in Children. Cognative Therapy and Research 1994;18:509-28.

36. Sayıl I, Palabıyıkoğlu R. Kriz ve Krize Müdahale Kurs Notları, Ankara: 1996. s33-61.

37. Ök M. 13-15 Yaş Grubu Ortaöğretim Öğrencilerinde Kaygı Düzeyi. Yüksek lisans Tezi, Dokuz Eylül Üniversitesi Sosyal bilimler Enstitüsü. 1990.

38. Dong Q, Yang B, Ollendick TH. Fears in Chinese Children and adolescent and Their Relation to Anxiety and Depression. J Child Psychol Psychiatry 1994;35:351-63.

39. O'Conner-Von S. Preparing children for surgery: An integrative research review. AORN J 2000;71:334-43.

40. Ollendick TH, Yang B, King NJ, Dong Q, Akande A. Fears in American, Australian, Chinese, and Nigerian children and adolescents: a cross-cultural study. J Child Psychol Psychiatry 1996;37:213-20.

41. Yiğit R. Hastaneye Yatmanın Çocuk ve Aile Üzerine Etkileri. T.H.D 1997;1:21-8.

42. Çakıroğlu S. Pediatrik onkoloji kliniklerinde oyunun önemi. Hemşirelik Bülteni 1991;5:7-11.

43. Eren A. Korku Kültürü, Değerler Kültürü ve Şiddet. Aile ve Toplum Eğitim Kültür ve Araştırma Dergisi 2005;7:20-4.

44. Savaşer S. Hastaneye Yatan Değişik Yaş Gruplarındaki Çocukların Hastalığa, Hastaneye ve Çevreye Reaksiyonu. Hemşirelik Bülteni 1986;2:53.

45. Girgin G. Farklı Sosyo Ekonomik Kesimden 13-15 Yaş Grubu Öğrencilerde Kaygı Alanları ve Kaygı Düzeylerinin Başarıyla Illişkisi.(Yayınlanmamış Tez). Yüksek Lisans Tezi Dokuz Eylül Üniversitesi, Sosyal Bilimler Enstitüsü. 1990.

46. Şahan D. Çocuk Hastaların Hastaneye Illişkin Korkuları ve Korkuyu Etkileyen Etmenlerin Incelenmesi.(Yayın yıllı 2006). Ege Üniversitesi Sağlık Bilimleri Enstitüsü, "Yüksek Lisans Tezi", 1997, Izmir.

47. Gardiner HW, Gander MJi. (Çev: Dönmez A, Çelen N, Onur B.) Çocuk ve Ergen Gelişimi, 4.Basım, Ankara: Imge Kitapevi Yayınları, 2001. s372- 373, s382-383.

48. Ceylan SS, Turan T. Bir Illköğretim Okulunda Okul Sağlığı Hemşireliği Uygulama Sonuçlarının Değerlendirilmesi. Fırat Sağlık Hizmetleri Dergisi 2009;4:35-49. 